\title{
Geographic distribution and conservation status of Eulychnia ritteri Cullmann (Cactaceae), an endemic cactus from southern Peru
}

\author{
Distribución geográfica y estado de conservación de Eulychnia ritteri Cullmann (Cactaceae), \\ un cactus endémico del sur de Perú
}

\section{G. Anthony Pauca-Tanco*1}

https://orcid.org/0000-0001-6367-5345

gpaucat@unsa.edu.pe

\section{Margarita Balvin ${ }^{2}$ \\ https://orcid.org/0000-0001-9219-7418 \\ mbalvinagu@gmail.com \\ Paul Hoxey ${ }^{2}$ \\ https://orcid.org/0000-0003-4568-4568 paul.hoxey@gmail.com \\ Víctor Quipuscoa ${ }^{1,2}$ \\ https://orcid.org/0000-0003-4552-3772 vquipuscoas@hotmail.com \\ Johana del Pilar Quispe-Turpo ${ }^{3}$ \\ https://orcid.org/0000-0002-6428-7229 \\ johadelpilarlc@gmail.com}

\section{*Corresponding author}

1 Universidad Nacional de San Agustín de Arequipa, San Agustín 107, Arequipa, Perú.

2 Instituto Científico Michael Owen Dillon, Jorge Chávez 610, Arequipa, Perú.

3 Universidad Católica San Pablo, Quinta Vivanco s/n, Urb. Campiña Paisajista, Arequipa.

\section{Citación}

Pauca-Tanco GA, Balvin M, Quipuscoa V, Hoxey P, Quispe-Turpo J de P. 2021. Geographical distribution and conservation status of Eulychnia ritteri Cullmann (Cactaceae), endemic cacti from southern Peru. Revista peruana de biología 28(4): e21623 (Noviembre 2021). doi: http://dx.doi.org/10.15381/rpb v28i4.21623

$\begin{array}{ll}\text { Presentado: } & 14 / 12 / 2020 \\ \text { Aceptado: } & 18 / 05 / 2021 \\ \text { Publicado online: } & 26 / 11 / 2021 \\ & \\ \text { Editor: } & \text { Cesar Arana }\end{array}$

Cesar Arana

\begin{abstract}
Eulychnia ritteri is endemic to Peru, restricted to the northern coast of the department of Arequipa. The lack of knowledge of this species, and threats such as human activities and climate change, put the populations at risk. In this research, we examined the geographical distribution and conservation status of $E$. ritteri in the coastal area of the Caraveli province. In addition, the population structure and phenology in the Quebrada Vizcachani population were evaluated using plots of $10 \times 100 \mathrm{~m}$. Data on the accompanying flora and local fauna were also obtained. Eulychnia ritteri showed five populations distributed from $15^{\circ} 43^{\prime}$ to $15^{\circ} 47^{\prime} \mathrm{S}$, with a total area of $63.62 \mathrm{ha}\left(0.63 \mathrm{~km}^{2}\right)$. The Quebrada Vizcachani population is the largest ( $24.5 \mathrm{ha}$ ) and the Cementerio population the smallest ( $0.018 \mathrm{ha}$ ). The population density evaluated is $0.06 \mathrm{ind} / \mathrm{m}^{2}$, where seedlings, juveniles, adults, and dead plants were $3.61,24.09,56.63$ and $15.67 \%$ respectively. The phenology was asynchronous, the flower buds, flowers and fruits appear in the same period. The flowers and fruits were food for insects and rodents respectively, and 18 accompanying species have been recorded. Finally, E. ritteri is categorised as endangered (EN), given its geographical distribution and identified threats.
\end{abstract}

\section{Resumen}

Eulychnia ritteri es una especie endémica del Perú, restringida a la costa norte del departamento de Arequipa. El poco conocimiento sobre esta especie, sumado a las amenazas por actividades antrópicas y cambio climático ponen en riesgo a sus poblaciones. En esta investigación se da a conocer la distribución geográfica y estado de conservación de E. ritteri en la zona costera de la provincia de Caravelí. Además, se evaluó la estructura poblacional y fenología en la población de Quebrada Vizcachani mediante parcelas de 10×100 m. Asimismo, se obtuvieron datos sobre la flora acompañante y fauna local. Eulychnia ritteri presentó cinco poblaciones distribuidas entre los $15^{\circ} 43^{\prime}$ a $15^{\circ} 47^{\prime} \mathrm{S}$, con una superficie total de 63.62 ha $(0.63$ $\mathrm{km}^{2}$ ). La población de Quebrada Vizcachani fue la de mayor extensión ( $24.5 \mathrm{ha}$ ) y la población de Cementerio la más pequeña $(0.018 \mathrm{ha}$ ). La densidad de la población evaluada es de $0.06 \mathrm{ind} / \mathrm{m}^{2}$, donde las plántulas, juveniles, adultos y plantas muertas, representaron el $3.61,24.09,56.63$ y $15.67 \%$ respectivamente. La fenología es asincrónica, los botones florales, flores y frutos se presentan en el mismo periodo. Las flores y frutos sirven de alimento para insectos y roedores respectivamente, y se han registrado 18 especies acompañantes. Por último, $E$. ritteri es categorizada como en peligro (EN), debido a su distribución geográfica y amenazas identificadas.

Keywords:

Endangered; endemic; Lomas; Peruvian desert; climate change.

Palabras clave:

En peligro de extinción; endémico; lomas; desierto peruano; cambio climático. 


\section{Introduction}

The Peruvian-Chilean desert is considered one of the most arid in the world (Rundel et al. 1991, Dillon 1997), and is home to a great diversity of species (Pinto \& Luebert 2009, Dillon et al. 2011, Quipuscoa et al. 2016, Talavera et al. 2017, Whaley et al. 2019). Despite the extreme drought, this area is home to the so-called fog oases or "Lomas". The Lomas are plant communities that develop due to the humidity from the Pacific Ocean. During the southern winter, a layer of stratocumulus clouds (from 600 to $1200 \mathrm{~m}$ above sea level) enters the continent (Oka \& Ogawa 1982, Ogawa et al. 1986), hitting hills adjacent to the coastal strip (whose peaks reach $1300 \mathrm{~m}$ ), and condensing over some surfaces on the ground, such as rocks, or perennial plants. Sometimes, when a very intense regime of clouds can occur, the so-called "garúa", which is a very fine and persistent mist (Weberbauer 1945, Ferreyra 1993, Jiménez et al. 2012). At the end of the winter, when the flow of fog stops, it is possible to observe exuberant vegetation development (Ono 1986, Jiménez et al. 2012).

Although most of the plants that develop in Lomas are annuals, there are also some perennials such as "tara" trees (Tara spinosa), and shrubs (Citharexylum flexuosum, Randia rotundifolia), including cacti (Talavera et al. 2017, Pauca \& Quipuscoa 2017, Pauca et al. 2018, Ostolaza 2019). Cacti in the Peruvian coast present a considerable diversity and endemism (Pauca \& Quipuscoa 2017, Ostolaza 2019). Particularly, in the Arequipa department are known seven cactus species exclusive to its coastal territory (Pauca \& Quipuscoa 2017), and Eulychnia ritte$r i$ has one of the most restricted distributions (Pauca et al. 2018, Pauca \& Quipuscoa 2017).

Eulychnia ritteri is an arborescent species, with a main stem, which at a certain height develops branches; presents pink daytime flowers, and orange fleshy fruits (Pauca et al. 2018, Ostolaza 2019). Some authors consider it to be a subspecies of E. iquiquensis or E. breviflora (Hunt et al. 2006), however, Ostolaza (2019) and Pauca and Quipuscoa (2017) consider it a good species, which is corroborated by molecular studies by Larridon et al. (2018) and Merklinger et al. (2021). Two populations of E. ritteri have been recorded in the province of Caravelí (north of Arequipa), specifically in the districts of Yauca and Chala (separated by approximately $23 \mathrm{~km}$ ), with the former being located within the private conservation area of Lomas de Atiquipa, and the latter only presenting a few plants in poor condition (Pauca et al. 2018, Ostolaza 2019) near Chala. Its conservation status according to Ministerial Resolution No. 505-2016-MINAGRI and Ostolaza (2019) is EN (endangered). The Convention on International Trade in Endangered Species of Wild Fauna and Flora (CITES) lists it in Appendix II (MINAM 2016) and the IUCN categorises it as LC (minor concern) (Cáceres et al. 2017). However, the IUCN considers E. ritteri to be a subspecies of E. iquiquensis.

Currently, the conservation status of many cactus species is worrying, especially those considered endemic and which form part of the Lomas ecosystem, as they are threatened by the pressure generated by anthropogenic activities such as: informal mining, construction of infrastructure, overgrazing, urban expansion (Jiménez et al. 2012, Pollack et al. 2020) and climate change (alteration of humidity cycles, increased aridity) (Schulz et al. 2011a, 2011b, García et al. 2014, Larridon et al. 2014). Therefore, this research aims to determine the real geographical distribution of the species, to record some aspects of phenology and population structure, and evaluate the conservation status of Eulychnia ritteri in southern Peru.

\section{Material and methods}

Study area. - Caravelí province is in the northwest of the department of Arequipa. Its coastal area comprises eight districts, from $15^{\circ} 27^{\prime}$ to $16^{\circ} 24^{\prime} \mathrm{S}$ (Fig. 1). The landscape is desert-like, with the old coastal mountain range, some valleys with rivers flowing down from the high Andes and the last foothills of the Andes. In general, to the south, near the seacoast, there are cliffs and dunes, crossed by small ravines. To the north, the cliffs disappear and are replaced by sandy-rocky plains, which reach 300 $\mathrm{m}$ above sea level. At higher elevations, we find hills that can reach $1300 \mathrm{~m}$ and on whose western slopes fog-dependent vegetation can develop. The climate is typically arid, with humidity during the winter months, however, during El Niño events, heavy rainfall can occur.

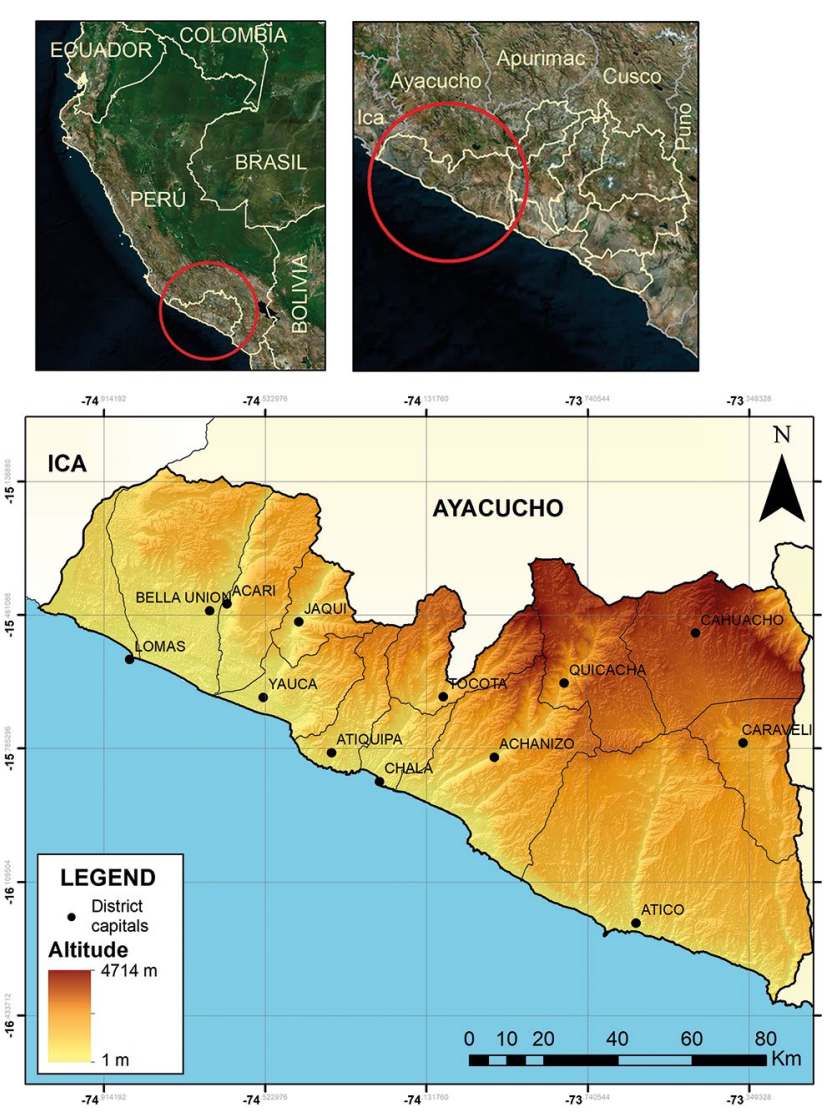

Figure 1. Map of the study area. Above, localization of Arequipa departamento (left) and Caravelí province (right). Below, Caravelí province. 
Geographical distribution. - We conducted the field visits in the coastal hills of Caraveli province between September 2017 and October 2018. In many cases, due to the inaccessibility of the terrain, we made the observations with the help of binoculars and cameras with $60 \mathrm{x}$ magnification. If an individual of E. ritteri could not be georeferenced directly, its approximate geographic position was calculated with the help of a high-resolution satellite image and a GPS device. All geographical points were recorded in a database.

With the records obtained, we make distribution maps using QGis ver. 3.14 (QGIS 2020), by means of a minimum convex polygon (where the internal angles of the polygon should not exceed $180^{\circ}$, taking as a vertex the most distant individuals of the population). Finally, we calculated the extension of the area, its altitudinal range and geographic location.

Population observations. - We assessed populations in October 2018. The population in Quebrada Vizcachani that had the highest density (number of individuals) and was accessible (given that some populations are located on steep slopes) was assessed. We established three plots of $10 \times 100 \mathrm{~m}$, located transversally according to altitude (at 560, 580 and $600 \mathrm{~m}$ ). We counted the number of seedlings or recruits (plants $<10 \mathrm{~cm}$ high), juveniles (plants $>10 \mathrm{~cm}$ high with some branches, without signs of flowering or fruiting), adult plants (branched with signs or presence of flowering and fruiting) and dead plants (those with no live shoots and the central bark exposed) (Pinto 2007). As for the phenology, it was registered on the same plots. In addition, we measured the basal diameter and height of the plants, characterized the habitat, and documented the accompanying flora, and interrelationships with the local fauna.

Conservation status. - The category for E. ritteri was made according to IUCN criterion "B" (IUCN 2019), which is based on geographical distribution, having as fundamental parameters the extent of presence (EOO) and/or the area occupied (AOO). This criterion is applicable for populations with restricted and severely fragmented distributions, with a tendency to decline either by current or future short-term events.

\section{Results}

Geographical distribution of Eulychnia ritteri. Five populations were recorded, located from $15^{\circ} 43^{\prime}$ to $15^{\circ} 47^{\prime} \mathrm{S}$ and from 130 to $910 \mathrm{~m}$, covering 63.62 ha (Fig. 2). The two largest populations are located in the district of Yauca, in the Quebrada Vizcachani and Quebrada La Tajo (these are within the private conservation area Lomas de Atiquipa), two others in Chala (Quebrada Cementerio and Cerro Febres) and one in Cháparra (Quebrada Huaccllaco) (Table 1).
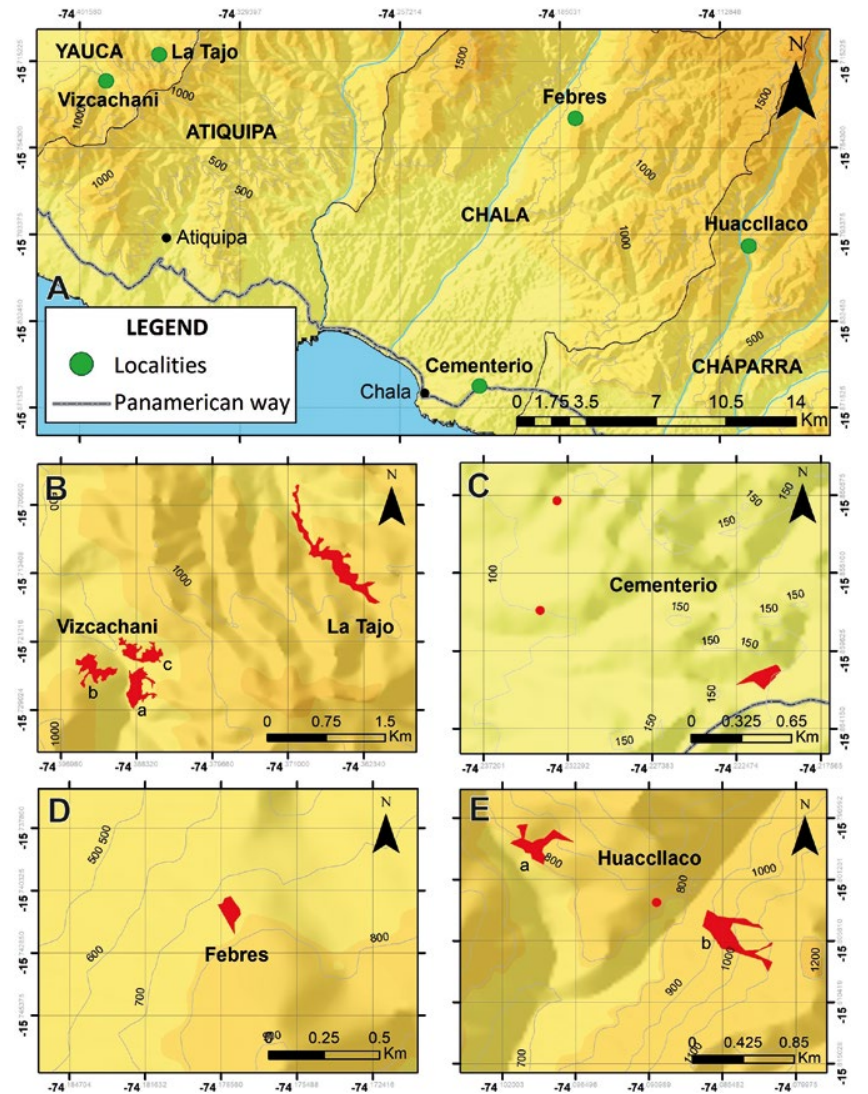

Figure 2. Geographical distribution of Eulychnia ritteri. (A) General distribution of E. ritteri; (B) Distribution in Yauca; (C) and (D) Distribution in Chala; and (E) Distribution in Cháparra.

Table 1. Location, extension, and altitudinal range of the areas occupied by Eulychnia ritteri.

\begin{tabular}{|c|c|c|c|c|}
\hline District & Locality & Location & Extension (ha) & Altitude (m) \\
\hline \multirow[t]{2}{*}{ Yauca } & Quebrada Vizcachani* & $\begin{array}{l}15^{\circ} 43^{\prime} 29.13^{\prime \prime} \mathrm{S} \\
74^{\circ} 23^{\prime} 21.76^{\prime \prime} \mathrm{W}\end{array}$ & $\begin{array}{l}8.1(\mathrm{a}) \\
8.7(\mathrm{~b}) \\
7.7(\mathrm{c})\end{array}$ & $540-850$ \\
\hline & Quebrada La Tajo & $\begin{array}{l}15^{\circ} 42^{\prime} 45.89^{\prime \prime} \mathrm{S} \\
74^{\circ} 21^{\prime} 54.99^{\prime \prime} \mathrm{W}\end{array}$ & 20.0 & $700-930$ \\
\hline \multirow{2}{*}{ Chala } & Quebrada Cementerio & $\begin{array}{l}15^{\circ} 51^{\prime} 40.26^{\prime \prime} \mathrm{S} \\
74^{\circ} 13^{\prime} 15.26^{\prime \prime} \mathrm{W}\end{array}$ & 0.018 & 130 \\
\hline & Cerro Febres & $\begin{array}{l}15^{\circ} 42^{\prime} 38.57^{\prime \prime} \mathrm{S} \\
74^{\circ} 08^{\prime} 55.24^{\prime \prime} \mathrm{W}\end{array}$ & 6.1 & $670-740$ \\
\hline Cháparra & Quebrada Huaccllaco & $\begin{array}{l}15^{\circ} 47^{\prime} 56.02^{\prime \prime} \mathrm{S} \\
74^{\circ} 05^{\prime} 58.42^{\prime \prime} \mathrm{W}\end{array}$ & $\begin{array}{l}4.8 \text { ha (a) } \\
8.2 \text { ha (b) }\end{array}$ & $790-910 \mathrm{~m}$ \\
\hline
\end{tabular}

* Three subpopulations in the Vizcachani ravine are indicated as a, b and c; and two subpopulations in Quebrada Huaccllaco are indicated as $a$ and $b$. 


\section{Population and habitat characteristics}

The total number of individuals in the five populations of E. ritteri are approximately 5500, with the largest number in Vizcachani (39.9\%), followed by La Tajo (33.8\%), Cerro Febres (23\%), Huaccllaco (3.1\%) and Cementerio $(0.2 \%)$. The population evaluated more closely (Vizcachani-a), presents a density of $0.06 \mathrm{ind} / \mathrm{m}^{2}$, where $3.61 \%$ were seedlings, $26.51 \%$ juveniles, $54.22 \%$ adults and $15.66 \%$ dead plants (Table 2, Fig. 3).
Measurements made on the main stems of seedlings, juveniles, adults, and dead plants, present average values of $2.27 \mathrm{~cm}, 6.2 \mathrm{~cm}, 19.2 \mathrm{~cm}$, and $19.5 \mathrm{~cm}$ respectively; the average height of the seedlings was $0.06 \mathrm{~m}$, juveniles 0.5 $\mathrm{m}$, adults $2.2 \mathrm{~m}$, and dead plants $2.1 \mathrm{~m}$. Regarding phenology, $35.71 \%$ were in a vegetative state and $64.29 \%$ showed reproductive signs (presence of flower buds, flowers in anthesis and fruits) (Figs. 4 and 5).

Table 2. Number of recruits, young plants, adult plants, dead plants and density, obtained from the plots evaluated in the sector of Vizcachani-a.

\begin{tabular}{clccccccc}
\hline Plot & Location & $\begin{array}{c}\text { Altitude } \\
\text { (m a.s.I.) }\end{array}$ & Recruits & $\begin{array}{c}\text { Young } \\
\text { plants }\end{array}$ & $\begin{array}{c}\text { Adult } \\
\text { plants }\end{array}$ & $\begin{array}{c}\text { Dead } \\
\text { plants }\end{array}$ & N & $\begin{array}{c}\text { Density } \\
\text { ind } / \mathbf{m}^{2}\end{array}$ \\
\hline 1 & $\begin{array}{l}15^{\circ} 43^{\prime} 37.64^{\prime \prime} \mathrm{S} \\
74^{\circ} 23^{\prime} 21.22^{\prime \prime} \mathrm{W}\end{array}$ & 560 & 0 & 16 & 40 & 14 & 70 & 0.07 \\
2 & $\begin{array}{l}15^{\circ} 43^{\prime} 37.62^{\prime \prime} \mathrm{S} \\
74^{\circ} 23^{\prime} 18.87^{\prime \prime} \mathrm{W}\end{array}$ & 580 & 6 & 14 & 30 & 8 & 58 & 0.06 \\
3 & $\begin{array}{l}15^{\circ} 43^{\prime} 37.62^{\prime \prime} \mathrm{S} \\
74^{\circ} 23^{\prime} 17.39^{\prime \prime} \mathrm{W}\end{array}$ & 600 & 0 & 10 & 24 & 4 & 38 & 0.04 \\
\hline
\end{tabular}

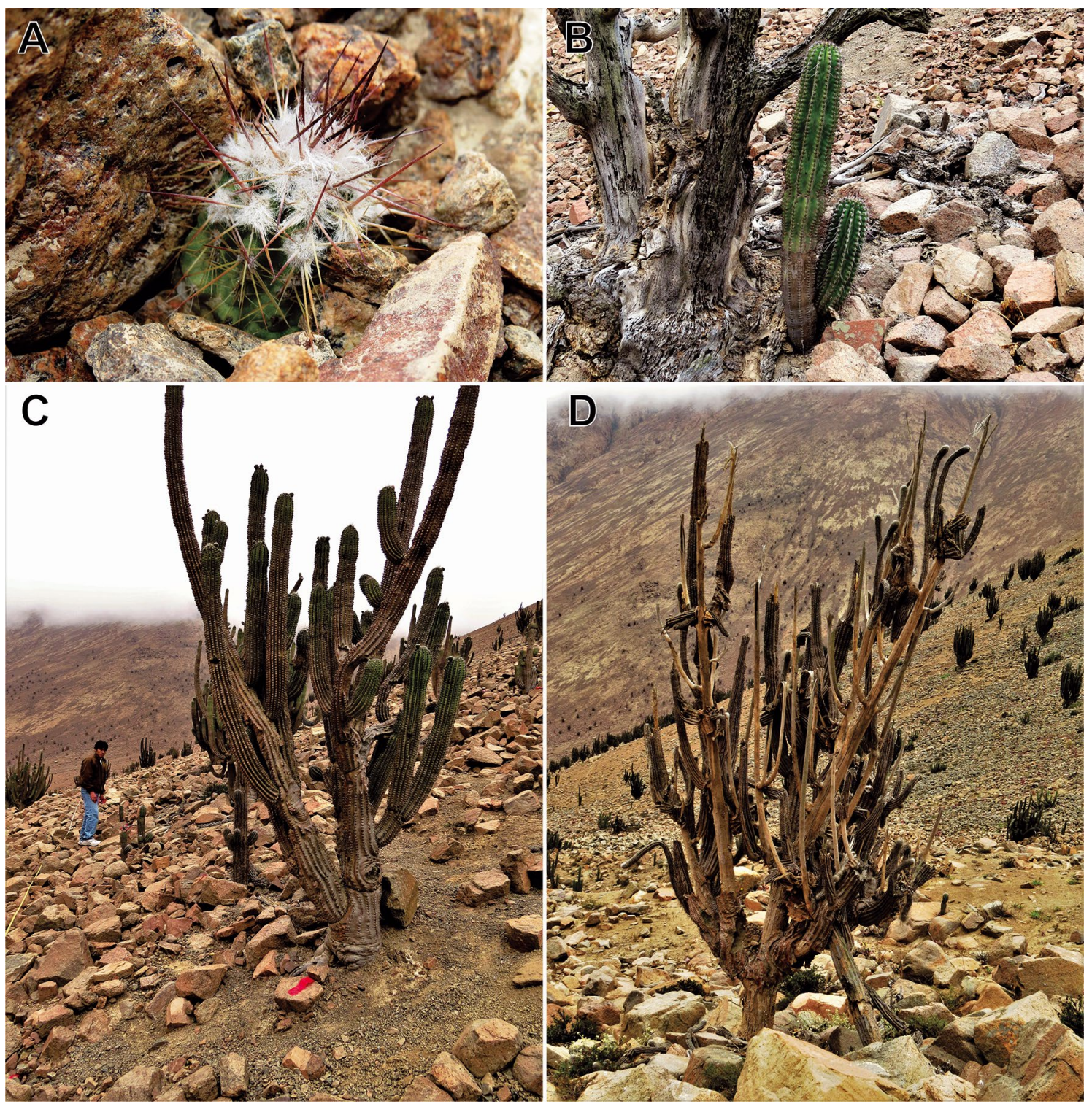

Figure 3. Individuals of Eulychnia ritteri in Vizcachani. (A) Recruit, (B) Young plant, (C) Adult plant and (D) Dead plant. 


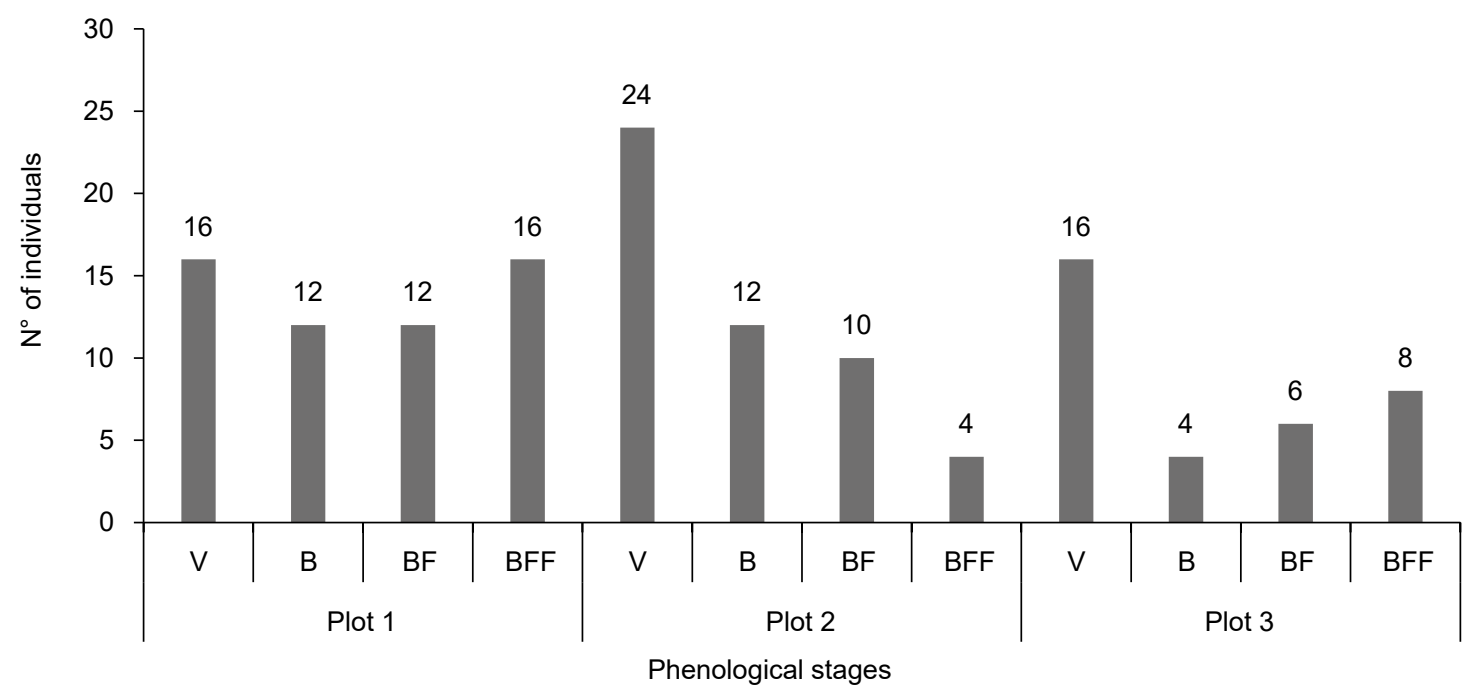

Figure 4. Phenological stages of individuals from the Vizcachani-a plots $(\mathrm{V}=$ vegetative, $\mathrm{B}=\mathrm{flower}$ bud, $\mathrm{BF}=$ flower bud + fruit, BFF = flower bud + flower + fruit $)$.

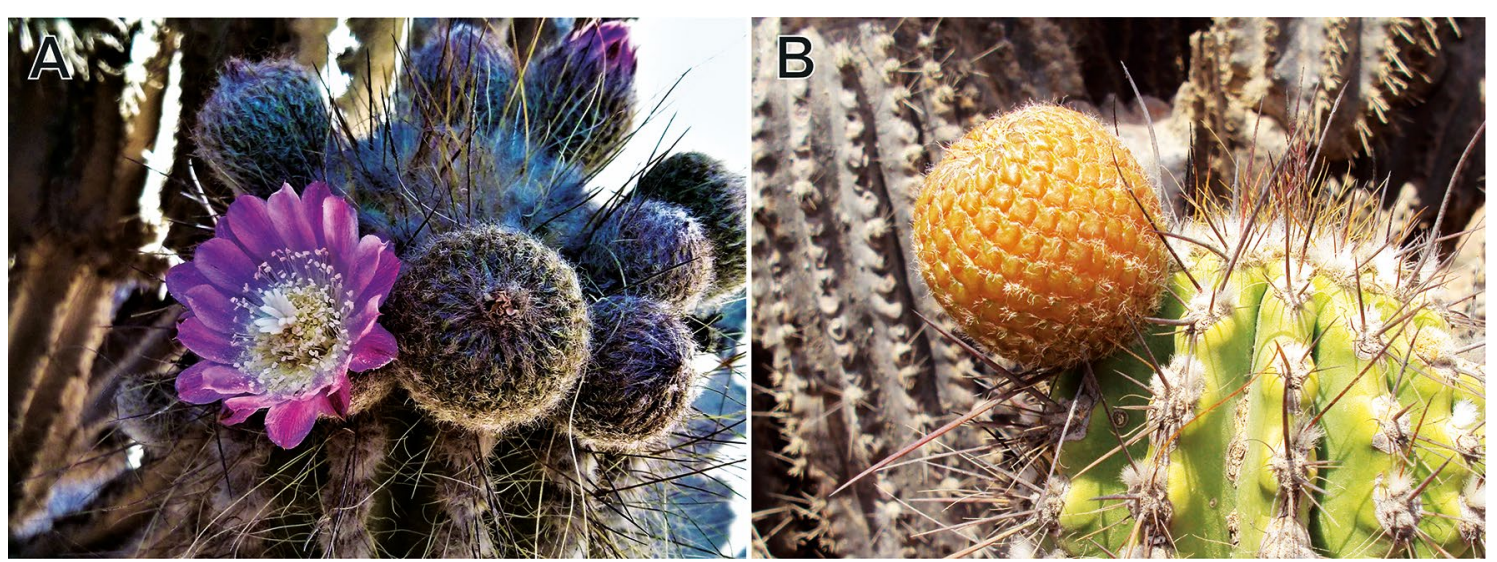

Figure 5. Eulychnia ritteri: (A) Flower buttons and mature flower, (B) Mature fruit.

Eulychnia ritteri inhabits very dry areas towards the leeward side of the hills, rocky, moderately sloping or steep terrain, in places where the fog from the ocean occasionally arrives and occasional rainfall can occur (Fig. 6). Some interrelations were observed, for example, the flowers are visited mainly by insects of the order Hymenoptera (Halictidae, Lasioglossum sp.), Coleoptera (Melyridae) and Lepidoptera (Hesperiidae, Pyrgus sp.). Some individuals of E. ritteri are used by the bird Pseudasthenes cactorum, to build their nests, while rodents (such as Lagidium peruanum) feed on the fruits, and probably contribute to dispersing the seeds in their faeces. The accompanying flora is mainly annuals (Onoseris odorata, Nolana chancoana, Cristaria multifida, Presliophytum sp. Malesherbia arequipensis, Tetragonia sp., Pteromonnina sp.). However, some perennials can be found (Trixis cacalioides, Heliotropium krauseanum, Ephedra americana, Waltheria ovata, Galvezia elisensii, Tillandsia purpurea) and other cactus species (Eriosyce islayensis, Weberbauerocereus weberbaueri, Neoraimondia arequipensis, Cumulopuntia tumida and Haageocereus decum- bens). In the Febres and Quebrada Huaccllaco sectors individuals of E. ritteri covered by lichens were observed.

Conservation status. - According to the established IUCN criteria (2019), E. ritteri is categorised as endangered (EN, B1a+B2ab (i,ii,iii,iv)), as the area of extent is in the range of $100-5000 \mathrm{~km}^{2}$ (B1a), the occupied area is less than $10 \mathrm{~km}^{2}$ (B2), the populations are observed to be fragmented and are $\leq 5$ (B2a). There is a projected trend towards a decrease in the extension and occupation of the area, a reduction in the quality of the habitat and a decrease in the number of localities or subpopulations (i,ii,iii,iv).

\section{Discussion}

Geographical distribution. - Eulychnia ritteri is an endemic species of Peru, restricted to certain areas of the Arequipa coast. Its current distribution covers a very small area, if compared to other Cactaceae species, such as Neoraimondia arequipensis, Corryocactus brevistylus or Browningia candelaris (Ostolaza 2019). In relation to the province of Caravelí, the area occupied by E. ritteri represents approximately only $0.005 \%$. 

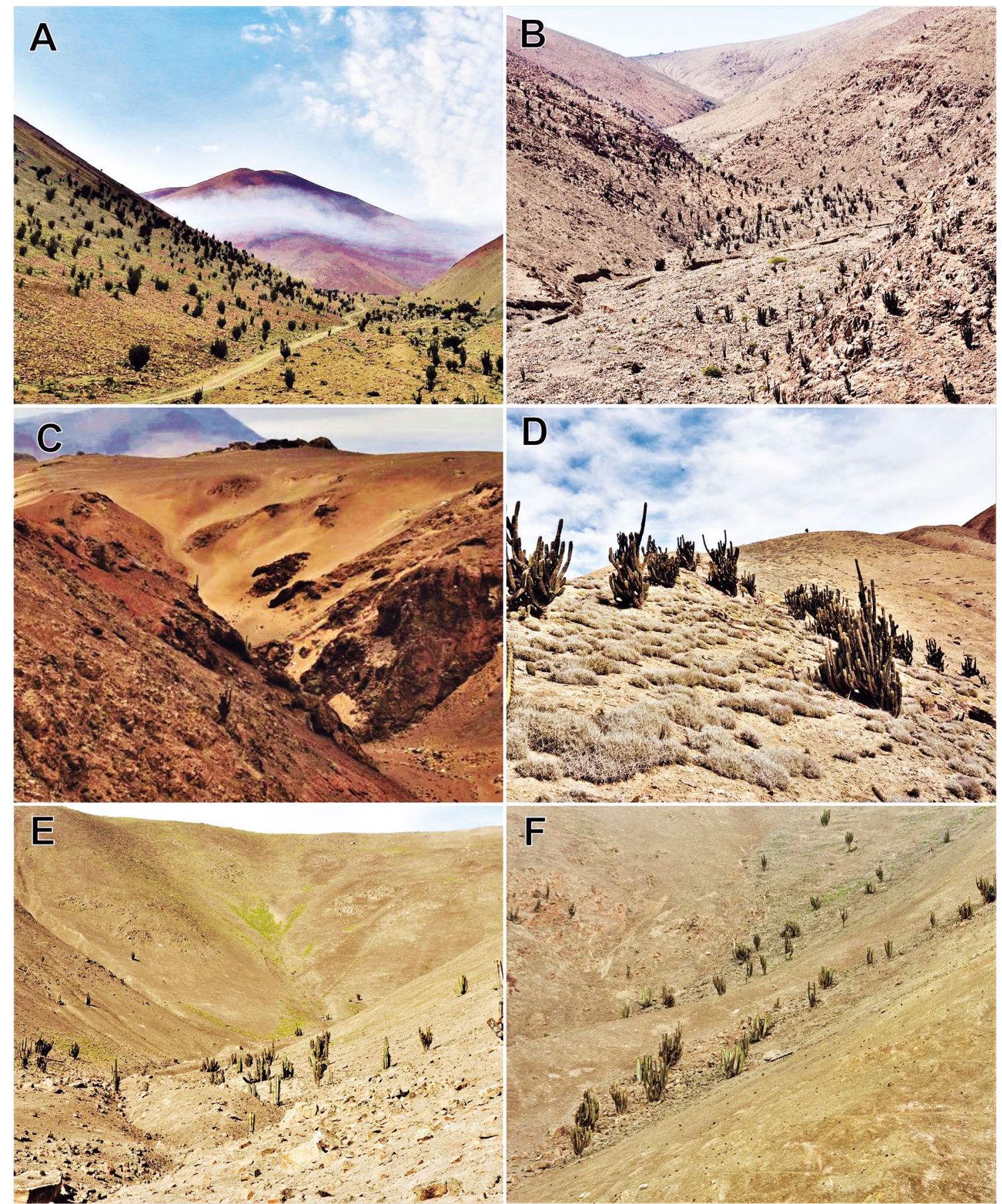

Figure 6. Habitat of Eulychnia ritteri in the towns of: (A) Vizcachani (Yauca); (B) La Tajo (Yauca); (C) Quebrada Cementerio (Chala); (D) Cerro Febres (Chala); (E) Quebrada Huaccllaco (Cháparra), subpopulation "a"; and (F) Quebrada Huaccllaco (Cháparra), subpopulation "b".

Explaining how E. ritteri has established itself in its current area of distribution requires further studies; it currently occupies a small area, about $560 \mathrm{~km}$ away from other Eulychnia species (the nearest population of Eulychnia iquiquensis is in northern Chile to the south of Arica). As mentioned by Donati et al. (2016) and Larridon et al. (2018), it is known that geographic isolation in Cactaceae has led to speciation. It is possible that ancestral Eulychnia species were distributed along the ancient PeruvianChilean coast, but due to changes in both geography and climate, populations disappeared between Arequipa and
Tacna. It is possible that E. ritteri emerged as part of a process of allopatric speciation (Merklinger et al. 2021).

On the other hand, trying to understand what are the determining factors for the current distribution of E. ritteri is important. It is documented that for Cactaceae, minimum temperature, precipitation and topography explain the distribution patterns at a regional scale, while chemical and physical properties of the soil are determining at a local scale (Hernández \& Bárcenas 1995, Godínez-Álvarez et al. 2003, Medel-Narvaez et al. 2006, Ruedas et al. 2006, Ribeiro-Silva et al. 2016). It seems 
that $E$. ritteri has adapted to specific conditions, given that all populations are located in areas where humidity is intermittent, there is high solar radiation and there is very limited rainfall. On the other hand, the soil also could play an important role, as the individuals are located on rocky slopes, which seems to be an advantage. In arid ecosystems, rocky soils, besides having low levels of organic matter, favour moisture retention, reduce temperature and evaporation (Teixeira et al. 2004, Fabre et al. 2006, Hughes et al. 2016), thus providing an adequate environment for recruitment and subsequent development of the plant (Castro et al. 2006, Gámez et al. 2018).

Population structure and habitat. - The assessed population shows a low density of individuals compared to other cactus species (Texeira et al. 2004, Ceroni et al. 2007, Castañeda-Romero et al. 2016, Zepeda et al. 2017, Loaiza and Molina-Moreira 2019), which may be related to the characteristics of the habitat where they are established and the strategies of the plant itself for its survival. There is probably competition between members of the population to obtain water and the distance between individuals has to be sufficient, so that each one receives what is necessary. It is known that some plants can act as nurse plants for their own or other species, but in arid places competition is high (especially for water) (Valiente et al. 1991). Possibly, E. ritteri presents some strategy to decrease the competition factor, because no plants were found under its canopy, even its own seedlings and juveniles are located at some distance, however, under dead plants if was possible to observe juveniles.

Likewise, in the population evaluated, the quantity of adult plants is dominant (with $56.63 \%$ ), the quantity of juveniles represents $24.1 \%$ and the seedlings are scarce (3.61\%). The low number of seedlings would be related to the environmental conditions not favourable for their germination and growth, since the seeds probably need rainfall as in a El Niño event (Pinto 2007, Godínez-Álvarez et al. 2003), while the development and permanence of the seedlings, will depend on the amount of humidity received afterwards. As mentioned by Pinto (2007) for E. iquiquensis, it is possible that during the El Niño event of 1982, juveniles have emerged and that the humidity conditions in the following years have been favourable. As for the seedlings, it is likely that they correspond to the 1998 El Niño event, but unlike the juveniles, they received less moisture (that is why they appear in smaller numbers). The above indicates the possible change that is taking place in the climate. As mentioned by Schultz et al. (2011a, 2011b), in the coastal area there is a decrease in humidity, which is corroborated by local inhabitants, who refer to the fact that droughts are more frequent.

The pattern of reproductive phenology for the population studied has been reported by Pauca et al. (2018), where, flower buds and flowers in anthesis are more abundant between spring and summer (October to March), and fruiting generally occurs during the summer. However, the reproductive stages in this species are asynchronous, given that they present flower buds, flowers and fruits in the same season. A similar case occurs in the phenology of E. iquiquensis and E. acida, which is advantageous, since only a part of the reproductive structures would be affected in the event of adverse conditions (biological or climatic), ensuring the longterm reproductive success (Pimienta-Barrios \& Nobel 1995, Pinto 2007, Salomón-Montijo et al. 2016, Salvatierra 2020). Asynchrony also benefits the associated fauna, as it results in a permanent source of food.

Conservation. - The outlook for E. ritteri appears to be somewhat encouraging, as despite the low number of seedlings, juvenile and adult plants are found in higher numbers; however, this conclusion is based on the data obtained in the single assessed population that is located within a private conservation area. The presence of some populations (Vizcachani and La Tajo creeks) within a conservation area, guarantees their protection against anthropic intervention, however, there are other problems, including climate change. Climatic impacts need to be studied, not only for E. ritteri, but also for the entire fog-dependent community.

Human activities are a threat to E. ritteri populations. Localities such as Cerro Febres and Quebrada Huaccllaco, not being in protected areas, can easily be transformed due to mining (through pits) and quarrying (removal of material), since this activity has been expanding in recent years (Pauca \& Quipuscoa 2015, Pollack et al. 2020). Impacts such as soil compaction and contamination, and construction of roads to transport minerals, would alter the surrounding communities and the landscape in general. The conservation status of the population in Quebrada Cementerio is the most dramatic. At present, there are only 14 widely dispersed adult plants, without the presence of seedlings or juvenile plants. The primary threat is urban expansion, given its proximity to the city of Chala.

Other threats that may affect all the populations of E. ritteri are linked to changes in climate and reduced seedling recruitment. According to Schulz et al. (2011a), the coastal zone is showing a reduction in humidity from the ocean, therefore plant communities (including cacti) would be compromised (Larridon et al. 2014). Perhaps, the adult individuals of $E$. ritteri, can persist for a time to these changes (given their adaptations), nevertheless, some processes like the germination and survival of the seedlings or phenological aspects, can be impacted. On the other hand, the isolation of populations can diminish viability, due to the lack of genetic exchange, as may be happening to the endemic tree Myrcianthes ferreyrae, which has isolated patches in the area of Atiquipa and Chala (Gonzales \& Villasante 2019).

According to IUCN guidelines (2019) and considering the restricted distribution and threats to the E. ritteri populations, the species has been categorised as endangered (EN). This is also in accordance with Larridon et al. (2014), the Ministerial Resolution No. 0505-2016-MINAGRI and Ostolaza (2019). On the other hand, the IUCN red list (Cáceres et al. 2017), locates it in LC (low concern) due to the fact that the IUCN categorisation was made considering E. ritteri to be a subspecies of E. iquiquensis, however this should change according to taxonomic and 
phylogenetic research (Larridon et al. 2018, Pauca et al. 2018, Merklinger et al. 2021), population characteristics, and in situ assessment of actual or potential threats. Another aspect to consider, and given the threats identified, is that the threat category of this species will likely increase, as the Chala population is the most susceptible and in the short term will become extinct.

Finally, although there are studies about the taxonomy and some ecological aspects of E. ritteri (Hunt 2013, Larridon et al. 2018, Pauca et al. 2018), little was known about its conservation status. These results will contribute to the implementation of strategies for conservation, mitigation, decision making, as well as encouraging studies on the ecology not only of this species, but also of those that make up the coastal Lomas communities, which in many cases are endemic.

\section{Conclusions}

Eulychnia ritteri has a restricted distribution in the coastal area of Caravelí province, in the districts of Yauca, Chala and Cháparra; the areas correspond to five populations, whose extensions vary from 0.018 ha (Chala) to 24.5 ha (Vizcachani), with a total of 63.62 ha $(0.64$ $\mathrm{km}^{2}$ ). The evaluation of the Vizcachani population shows an average density of $0.06 \mathrm{ind} / \mathrm{m}^{2}$, with young and adult individuals being the most abundant (with 24.1 and $56.63 \%$ respectively), while seedlings and dead specimens represented $3.61 \%$ and $15.67 \%$ respectively. The phenology is asynchronous, with flower buds, flowers, fruits, or the presence of all three stages together being beneficial for the associated fauna. Finally, E. ritteri is categorised as endangered (EN, B1a+B2ab (i,ii,iii,iv)), due to its small area of distribution, population fragmentation and population characteristics. The evident dangers for this species, whether short or long term, are defined in relation to human activities (mining, urban expansion) and climate change (decrease in humidity).

\section{Literature cited}

Cáceres F, Saldivia P, Guerrero P, Walter HE, Faúndez L. 2017. Eulychnia iquiquensis (amended version of 2013 assessment). The IUCN Red List of Threatened Species 2017: e.T152841A121550210. https://dx.doi.org/10.2305/IUCN.UK.2017-3.RLTS. T152841A121550210.en. Downloaded on 10 September 2020.

Castañeda-Romero M, Luna-Contreras M, Vela-Godinez D, Montoya-Santiago G, González-Bermúdez A, Martínez R, Esperón-Rodríguez M. 2016. Nota sobre la estructura poblacional de Echinocactus platyacanthus (Cactaceae) en la Reserva de la Biósfera "Barranca de Metztitlán", Hidalgo, México. Acta botánica mexicana 115: 65-73. https://doi.org/10.21829/ abm115.2016.1112

Castro V, Eyzaguirre R, Ceroni A. 2006. Supervivencia de plántulas de Melocactus peruvianus Vaupel y Haageocereus pseudomelanostele subsp. aureispinus (Rauh \& Backeberg) Ostolaza, en condiciones experimentales. Cerro Umarcata, valle del río Chillón, Lima. Ecología Aplicada 5(1-2): 61-66. http://dx.doi.org/10.21704/ rea.v5i1-2.318
Ceroni A, Castro V, Teixeira V, Redolfí I. 2007. Neoraimondia arequipensis subsp. roseiflora (Werdermann \& Backeberg) Ostolaza (Cactaceae): eje de las interacciones en ecosistemas áridos. Ecología Aplicada 6(1): 155-168.

Dillon MO. 1997. Lomas formations-Peru. In: S.D. Davis, V.H. Heywood, O. Herrera-McBryde, J. Villa-Lobos \& A.C. Hamilton, eds. Centres of Plant Diversity, A Guide and Strategy for their Conservation. WWF, Information Press, Oxford. Pp. 519-527.

Dillon M, Leiva S, Zapata M, Lezama P, Quipuscoa V. 2011. Floristic checklist of the Peruvian lomas formations. Arnaldoa 18(1): 7-32.

Donati D, Bianchi C, Pezzi G, Conte C, Hofer A, Chiarucci A. 2016. Biogeography and ecology of the genus Turbinicarpus (Cactaceae): Environmental controls of taxa richness and morphology. Systematics and Biodiversity 14: 1-11.

Fabre A, Gauquelin T, Villasante F, Ortega A, Puig H. 2006. Phosphorus content in five representative landscape units of the Lomas de Arequipa (Atacama Desert-Peru). Catena 65(1): 80-86. https://doi.org/10.1016/j.catena.2005.10.004

Ferreyra R. 1993. Los tipos de vegetación de la costa peruana. Anales del Jardín Botánico de Madrid 40 (1): 241-256.

Gámez C, Ríos R, López M. 2018. Caracterización ecológica y edáfica de Mammillaria compressa de Candolle (Cactaceae). In: M. Ortega, M. Martín, G. Nubes \& M. Robles, eds. Temas selectos de la flora silvestre de zonas áridas del noroeste de México. Universidad de Sonora, Sonora. Pp. 85-104.

García R, Miyashiro J, Orejón C, Pizarro F. 2014. Crecimiento urbano, cambio climático y ecosistemas frágiles: el caso de las lomas de Villa María del Triunfo en Lima Sur. In: W. Jungbluth, ed. Perú Hoy, Cambio climático. Poder, discursos y prácticas. DESCO, Lima. Pp. 275-297.

Godínez-Álvarez H, Valverde T, Ortega-Baes P. 2003. Demographic trends in the Cactaceae. The Botanical Review 69: 173-203. https://doi.org/10.1663/00068101(2003) 069[0173:DTITC]2.0.C0;2

Gonzales FN, Villasante F. 2019. Estado de conservación de Myrcianthes ferreyrae un árbol endémico de las lomas costeras del sur del Perú. Revista peruana de biología 26(2): 235-242. http://dx.doi.org/10.15381/rpb. v26i2.16380

Hernández HM, Bárcenas RT. 1995. Endangered cacti in the Chihuahuan Desert: I. Distribution patterns. Conservation Biology 9: 1176-1188.

Hughes FM, Jacobi CM, Borba EL. 2016. Fate of cohorts in Melocactus (Cactaceae) species is affected by rainfall uncertainty and microrelief structures. Brazilian Journal of Botany 39, 197-205. https://doi.org/10.1007/ s40415-014-0116-8

Hunt D. 2013. Eulychnia. Cactaceae Systematics Initiatives 29: 6-11.

Hunt D, Taylor N, Charles G. (2006). The New Cactus Lexicon. Dh Books, Somerset. Pp 1-373.

IUCN Standards and Petitions Committee. 2019. Guidelines for Using the IUCN Red List Categories and Criteria. Version 14. Prepared by the Standards and Petitions Committee. Downloadable from http://www.iucnredlist.org/documents/RedListGuidelines.pdf.

Jiménez P, Villegas L, Villasante F, Talavera C, Ortega A. 2012. Las Lomas de Atiquipa: agua en el desierto. In: F. Hajek, and P. Martínez, eds. ¿Gratis?: los servicios de la naturaleza y como sostenerlos en el Perú. SePerú, Lima. Pp. 159-170. 
Larridon I, Shaw K, Cisternas MA, Paizanni A, Sharrock S, Olfield S, Goetghebeur P, Samain MS. 2014. Is there a future for the Cactaceae genera Copiapoa, Eriosyce and Eulychnia? A status report of a prickly situation. Biodiversity and Conservation 23: 1249-1287. https://doi. org/10.1007/s10531-014-0664-Z

Larridon I, Walter HE, Guerrero PC, Duarte M, Cisternas MA, Hernández C, Bauters K, Asselman P, Goetghebeur P, Samain MS. 2015. An integrative approach to understanding the evolution and biodiversity of Copiapoa (Cactaceae), a threatened genus from Chile's Atacama Desert. American Journal of Botany 102: 1506-1520. https://doi.org/10.3732/ajb.1500168

Larridon I, Walter H, Rosas M, Vandomme V, Guerrero P. 2018. Evolutionary trends in the columnar cactus genus Eulychnia (Cactaceae) based on molecular phylogenetics, morphology, distribution, and habitat. Systematics and Biodiversity 16(7): 643-657. https://doi.org /10.1080/14772000.2018.1473898

Loaiza CR, Molina-Moreira N. 2019. Nuevo registro de Melocactus peruvianus (Cactaceae) y estado de conservación del género Melocactus en el Ecuador. Rodriguésia 70: e00842018. https://doi. org/10.1590/2175-7860201970064

Medel-Narvaez A, León de la Luz JL, Freaner-Martinez F, Molina-Freaner F. 2006. Patterns of abundance and population structure of Pachycereus pringlei (Cactaceae), a columnar cactus of the Sonoran Desert. Plant Ecology 187: 1-14. https://doi.org/10.1007/s11258-0069128-1

Merklinger FF, Bönert T, Arakaki M, Weigend M, Quandt D, Luebert F. 2021. Quaternary diversification of a columnar cactus in the driest place on earth. American Journal of Botany 108(2): 184-199.

MINAM (Ministerio del Ambiente). 2016. Lista de especies de flora peruana incluida en los Apéndices de CITES. Ministerio del Ambiente, Lima. 228 pp.

Ogawa H, Oka S, Ohga N, 1986. The meso and local-scale distribution of lomas vegetation and their determining factors in the coastal desert of southern Peru. In: M. Ono, ed. Taxonomic and Ecological Studies on the Lomas Vegetation in the Pacific Coast of Peru. Makino Herbarium, Tokyo Metropolitan University, Tokyo. Pp. 15-40.

Oka S, Ogawa H, 1982. Geographical distribution of the lomas vegetation and its climatic environments along the Pacific coast of Peru. In: M. Ono, ed. A Preliminary Report of Taxonomic and Ecological Studies on the Lomas Vegetation in the Pacific Coast of Peru. Makino Herbarium, Tokyo Metropolitan University, Tokyo. Pp. 19-36.

Ono M. 1986. Definition, classification and taxonomic significance of the Lomas vegetation. In: M. Ono, ed. Taxonomic and Ecological Studies on the Lomas Vegetation in the Pacific Coast of Peru. Makino Herbarium Tokyo Metropolitan University. Tokyo. Pp 5-14.

Ostolaza C. 2019. Todos los Cactus del Perú. 2nd edn. Sociedad Peruana de Cactáceas y Suculentas, Lima. 571 pp.

Pauca A. Quipuscoa V. 2017. Catálogo de las cactáceas de Arequipa, Perú. Arnaldoa 24(2): 447-496. http://doi. org/10.22497/arnaldoa.242.24204

Pauca A, Quipuscoa V. 2015. Corryocactus dillonii (Cactaceae), una nueva especie de la formación de lomas de Arequipa, Perú. Arnaldoa 22(2): 313-328.
Pauca A, Talavera C, Villasante F, Quispe J, Laura M. 2018. Cactaceae del distrito de Atiquipa y del Área de Conservación Privada Lomas de Atiquipa: aspectos taxonómicos, ecológicos y de distribución. Arnaldoa 25(3): 829-856. http://doi.org/10.22497/arnaldoa.253.25303

Pimienta-Barrios E, Nobel PS. 1995. Reproductive characteristics of Pitayo (Stenocereus queretaroensis) and their relationships with soluble sugars and irrigation. Journal of the American Society for Horticultural Science 120(6): 1082-1086.

Pinto R, Luebert F. 2009. Datos sobre la flora vascular del desierto costero de Arica y Tarapacá, Chile, y sus relaciones fitogeográficas con el sur de Perú. Gayana Botánica 66(1): 28-49. http://dx.doi.org/10.4067/ $\underline{\text { S0717-66432009000100004 }}$

Pinto R. 2007. Estado de conservación de Eulychnia iquiquensis (Schumann) Britton et rose (Cactaceae) en el extremo norte de Chile. Gayana Botánica 64(1): 98-109. http:// dx.doi.org/10.4067/S0717-66432007000100010

Pollack L, Rodríguez E, Leiva S, Saldaña I, Alvítez E, Briceño J, Gayoso G. 2020. Amenazas y desastres antrópicos frecuentes en el Área de Conservación Privada (ACP) Lomas Cerro Campana (provincias Trujillo y Ascope, región La Libertad, Perú). Arnaldoa 27(1): e53-e63. http://doi.org/10.22497/arnaldoa.271.27103

QGIS.org, 2020. QGIS Geographic Information System. QGIS Association. http://www.qgis.org

Quipuscoa V, Tejada C, Fernández C, Durand K, Pauca A, Dillon M. 2016. Diversidad de plantas vasculares de las Lomas de Yuta, provincia de Islay, Arequipa Perú. 2016. Arnaldoa 23(2): 517-546. http://doi.org./10.22497/ arnaldoa.232.23207

Ribeiro-Silva S, Medeiros MB, Lima V, Peixoto MR, Aona L. 2016. Patterns of Cactaceae species distribution in a protected area in the semiarid Caatinga Biome of North-Eastern Brazil. Edinburgh Journal of Botany 73(2): 157170. https://doi.org/10.1017/S0960428616000044

RM N 505-2016-MINAGRI. 2016. Disponen la prepublicación del proyecto de Decreto Supremo que aprueba las listas de Clasificación Oficial de Especies de Flora Silvestre Categorizadas como Amenazadas, en los portales institucionales del Ministerio de Agricultura y Riego y del SERFOR. 29 de setiembre de 2016. El Peruano Normal Legales: 600597-600598.

Ruedas M, Valverde T, Zavala-Hurtado JA. 2006. Analysis of the factors that affect the distribution and abundance of three Neobuxbaumia species (Cactaceae) that differ in their degree of rarity. Acta Oecologica 29(2): 155-164. http://dx.doi.org/10.1016/j.actao.2005.09.002

Rundel P, Dillon M, Palma B, Money H, Gulmon L, Ehleringer J. 1991. The phytogeography and ecology of the coastal Atacama and Peruvian deserts. Aliso 13(1): 1-49.

Salomón-Montijo B, Reyes-Olivas Á, Sánchez-Soto BH. 2016. Fenología reproductiva de Stenocereus thurberi (Cactaceae) en una región de transición del norte de Sinaloa, México. Gayana Botánica 73(2): 381-390. https:// dx.doi.org/10.4067/S0717-66432016000200381

Salvatierra A. 2020. Reproductive phenology of the arborescent cactus Eulychnia acida Phil. under three agroecological conditions in the Coquimbo Region, Chile. Chilean Journal of Agricultural Research 80(2): 253-262. http://dx.doi.org/10.4067/S0718$\underline{58392020000200253}$ 
Schulz N, Aceituno P, Richter M. 2011a. Phytogeographic divisions, climate change and plant dieback along the coastal desert of northern Chile. Erdkunde 2: 169187. http://doi.org/10.3112/erdkunde.2011.02.05

Schulz N, Boisier J, Aceituno P. 2011b. Climate change along the arid coast of northern Chile. International Journal of Climatology 32:1803-1814. https://doi.org/10.1002/ joc.2395

Talavera C, Pauca A, Fernández C, Villasante F, Villegas L. Delgado A. 2017. Flora de Lomas de Atiquipa. Universidad Nacional de San Agustín de Arequipa, Arequipa. 167 pp.

Teixeira V, Castro V, Ceroni A, Eyzaguirre R. 2004. Diversidad y densidad de la comunidad de cactáceas en el cerro Umarcata y Quebrada Orobel en el valle del río Chillón (Lima) y su relación con los factores edáficos. Ecología Aplicada 3(1,2): 1-8.

Valiente A, Vite F, Zavala A. 1991. Interaction between the cactus Neobuxbaumia tetetzo and the nurse shrub Mimosa luisana. Journal of Vegetation Science 2: 11-14.

Weberbauer A. 1945. El Mundo Vegetal de los Andes Peruanos (Estudio fitogeográfico). Ministerio de Agricultura, Lima. $776 \mathrm{pp}$.

Whaley O, Orellana-García A, Pecho-Quispe J. 2019. An annotated checklist to vascular flora of the Ica Region, Peru -with notes on endemic species, habitat, climate and agrobiodiversity. Phytotaxa 389 (1): 1-125. http:// dx.doi.org/10.11646/phytotaxa.389.1.1

Zepeda V, Golubov J, Mandujano MC. 2017. Distribución espacial, estructura de tamaños y reproducción de Astrophytum ornatum (Cactaceae). Acta botánica mexicana 119: 35-49. https://doi.org/10.21829/ $\underline{\mathrm{abm} 119.2017 .1230}$
Agradecimientos / Acknowledgments:

To Miguel and Jesús Ardiles, Joe Calcina, Robert Cornejo and Cesar Luque, for their help during the population assessments. To Luis Villegas Paredes, who gave technical support to this research. To Luis Roberto de la Torre Cárcamo, president of the Atiquipa Peasant Community, for his willingness and disinterested help. To all those who collaborated with this research.

Conflicto de intereses / Competing interests:

The authors declare no conflict of interest.

Rol de los autores / Authors Roles:

GAPT: Conceptualization of the study. GAPT, MB, VQ, PH, JPQT: visits and data collection in the field. GAPT, JPQT: data analysis. GAPT, MB, PH: writing of the manuscript. GAPT, MB, VQ, PH, JPQT: Writing, reviewing and editing.

Fuentes de financiamiento / Funding:

The authors declare, this work not received specific funding.

Aspectos éticos / legales; Ethics / legals:

Authors declare that they did not violate or omit ethical or legal norms in this research. 